\title{
Biology and distribution of the declining moth Ethmia pyrausta (Pallas, 1771), with description of the larva (Gelechioidea, Depressariidae, Ethmiinae)
}

\author{
Kari Nupponen ${ }^{1}$, Matti Ahola $^{2}$, Marko NiEmineN $^{3}$, Urmas JÜrivete ${ }^{4}$ \\ 1 Merenneidontie 19 D, FIN-02320 Espoo, Finland; email: Kari.Nupponen@kolumbus.fi \\ 2 Metsänreunantie 27 G, FIN-85900 Reisjärvi, Finland; email: MJ.Ahola@kotinet.com \\ 3 Department of Biosciences, University of Helsinki, PO Box 65 (Viikinkaari 1), FI-00014 University of Helsinki, Finland \\ 4 MooraUmb 8,EE-11625 Tallinn, Estonia; email: urmas@kolmabi.ee \\ http://zoobank.org/90EF92E0-D58D-439C-957A-90735EC15611
}

Received 27 November 2014; accepted 8 January 2015; published: 17 March 2015

Subject Editor: Erik van Nieukerken.

\begin{abstract}
Records of Ethmia pyrausta (Pallas, 1771) from the Baltic countries, the British Isles and Fennoscandia are listed. All known aspects of habitat requirements, larval biology and adult behaviour, mostly based on our own observations in the field, are described. Instructions for conservation and habitat management are presented. The larva is described and illustrated in detail.
\end{abstract}

\section{Introduction, material and methods}

Ethmia pyrausta (Pallas, 1771) (Figs 1,2) is one of the rarities in the European fauna of the subfamily Ethmiinae. The species occurs sporadically in the hemiboreal zone in western and central parts of the Palaearctic region. Most of the records are old and the species is considered to be declining at least in its European distribution range. Although the larval host plant(s) and the flight period of the adult are known, there are very scarce data available on the behaviour of larvae and adults, as well as on the preferred habitats of the species.

During 2002-2006, the present occurrence and status of the populations of all protected Lepidoptera species was evaluated on the Alland Islands in the SW Finnish archipelago by Faunatica Oy (Nupponen et al. 2007). One of the fifteen focal species was E. pyrausta, which was known to have occurred on the islands, but no confirmed records of the species existed since the 1950s. One abundant population was discovered in 2005 by Kari Nupponen in the central part of the main island, where there were two studies of the larval behaviour (in July 2005 and 2006; Figs 3, 4). The species was also recorded close to the southern coast of Åland, where a single male was observed in early June, 2006, by Erkki and Leena Laasonen. Ene and Urmas Jürivete discovered another abundant population of E. pyrausta from SE Estonia in 2007, and adult behaviour was studied there in May 2008.

The description of the larva (below, Figs 5-10) is based on two caterpillars from Finström, Åland Island (25.vii.2006, see Table 1). The larvae were preserved in ethanol in the field, and later studied by Matti Ahola. The hypopharyngeal complex, mandibles and labrum of the larval 


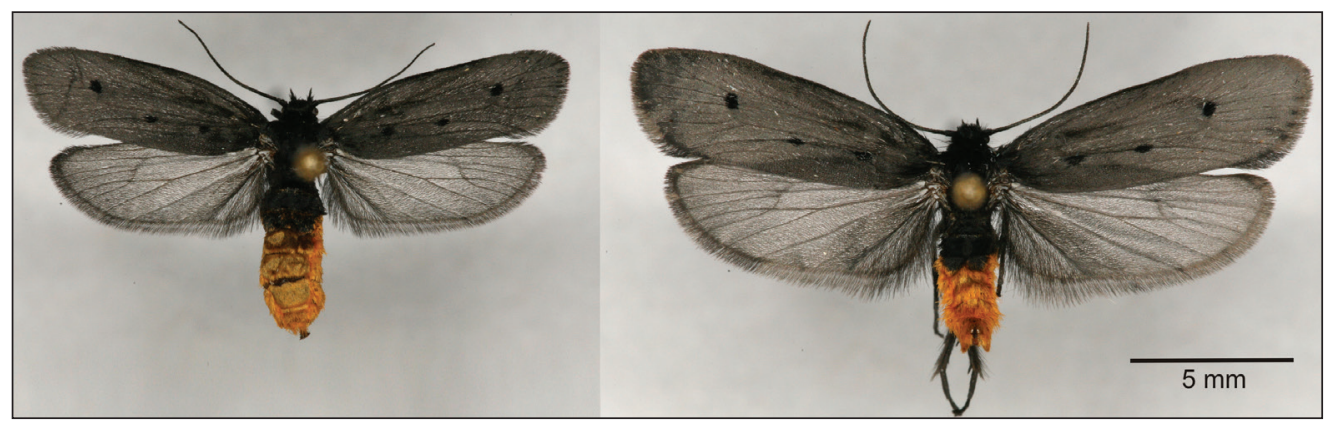

Figure 1. Adults of Ethmia pyrausta (Pallas, 1771) (Finland, Al: Finström, e.l., larvae found 25.vii.2006 on Thalictrum flavum).

head were dissected and mounted on slide. The chaetotaxy was studied from larvae in alcohol, and the living larva (Fig. 4) was photographed to show the habitus. Naming of the setae follows Hinton (1946) as interpreted by Ahola and Silvonen (2005).

\section{Distribution}

Ethmia pyrausta was described from the Samara region, the eastern part of European Russia, in the $18^{\text {th }}$ century (Sattler 1967). There are two recent records of E. pyrausta from the steppes of the Ural Mountains (Nupponen in press) and another one from Uljanovsk district (W. Mey, pers. comm.), but apparently the species is very rare in the Volgo-Ural region. In Russia, the species is known to occur widely but sporadically in the hemiboreal zone, from Karelia in the west to the Baikal region in the east (Sinev 2008). It is also known from Mongolia (Ulan-Bator) and China (Kuldzha, Xinjiang) (Dubatolov et al. 1997, Dubatolov 2014). In western Europe, E. pyrausta occurs only in Scotland, Sweden, Finland and the Baltic countries.

In Scotland, E. pyrausta is restricted to the Highlands. It was known by a single specimen discovered in May 1853 on the banks of the River Shin, until two specimens were unexpectedly found in 1996 in the Cairngorms (about 1000 m a.s.1.) (Anonymous 2014; Kimber 2014). Subsequently several further specimens were found, one at Loch Vrotachan on the NNW end of Cairnwell, Aberdeenshire (810 m a.s.1., 28.v.2001), one at the River Averon close to Loch Morie, East Ross-shire (8.v.2008), one on the slopes of Ben Griam Mor in 2012, and 15 specimens in Croick Estate (24.iv.-31.v.2014) (Anonymous 2014).

In Sweden, E. pyrausta has declined severely. It has been recorded in eight provinces in the central part of the country (Gustafsson 2012). However, only from two provinces, viz. Uppland and Dalarna, are there rather recent records. Here the moth occurs along the River Dalälven, but no records are known from the most recent years (Nils Ryrholm, pers. comm.).

In Finland, E. pyrausta occurs with certainty only on the Åland Islands, where it is apparently declining due to habitat loss. Most records are from the 1940s and 1950s, and many populations have vanished since (Nupponen et al. 2007). Since the 1950s, there are only confirmed records from two localities. Additionally, there is a single record of the species from the southern coast of the Finnish mainland (Helsinki, 1 larva, 1946; Hyönteistietokanta 2014), thus its occurrence in southern Finland cannot be excluded. 


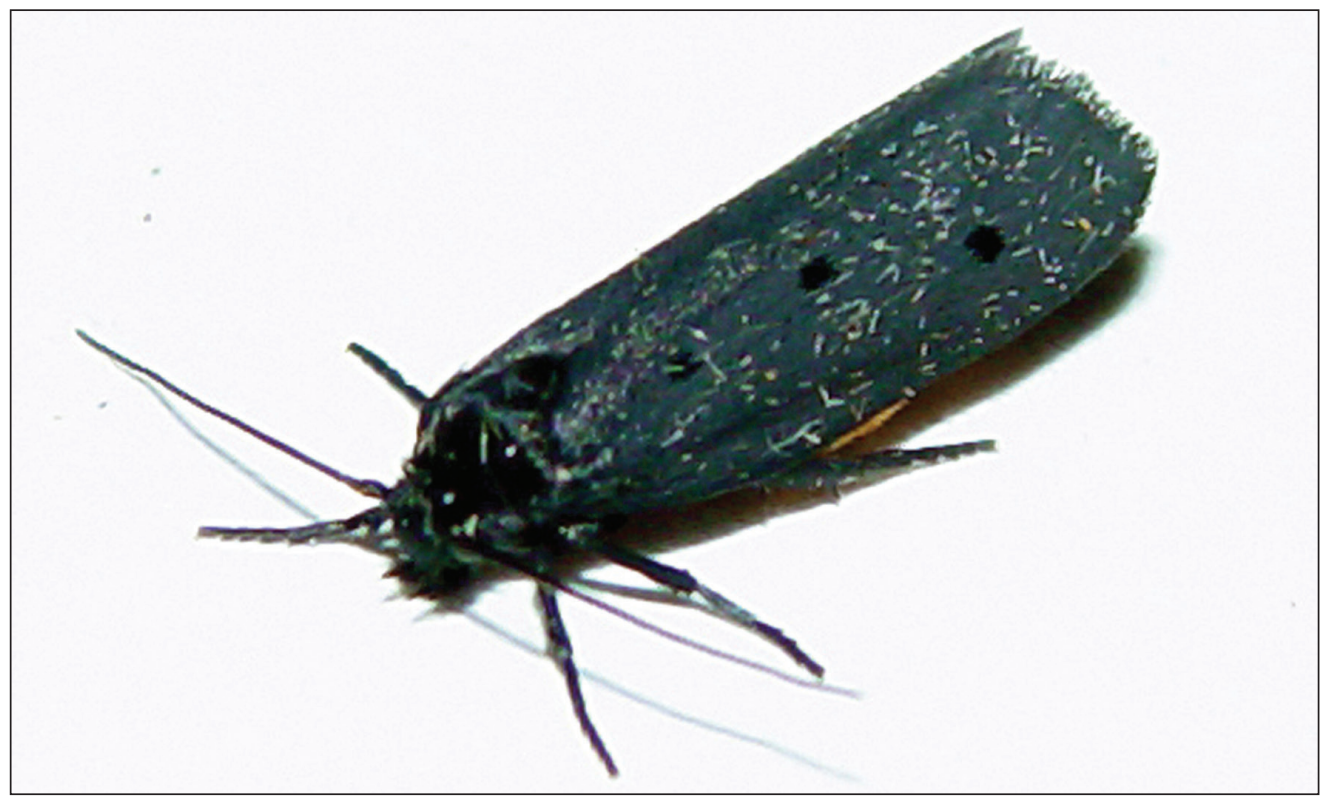

Figure 2. Female of Ethmia pyrausta in resting posture (Finland, Al: Finström, e.l., larva found 25.vii.2006).

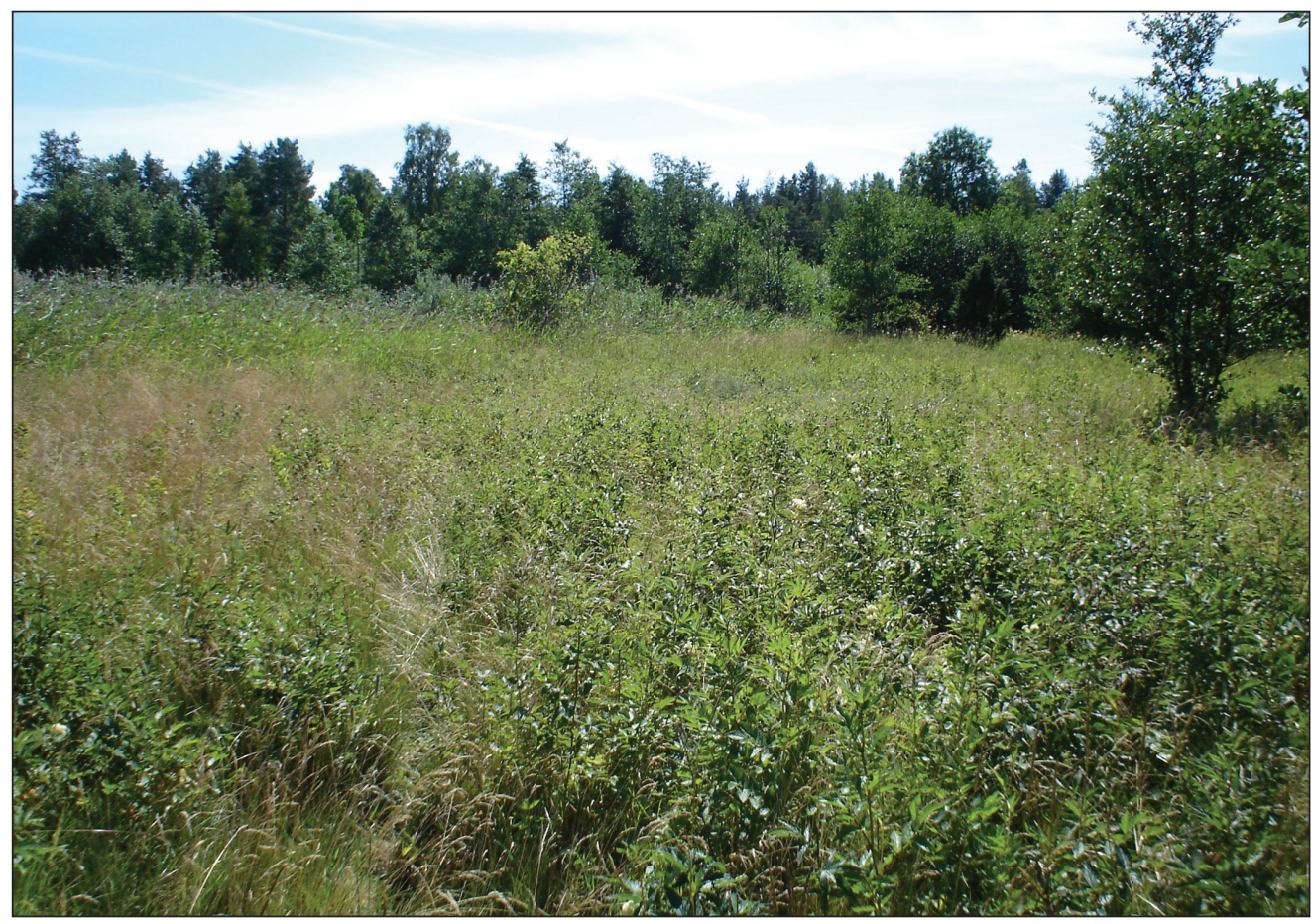

Figure 3. Moist meadow in Finström, central Åland Islands. Habitat of Ethmia pyrausta (photo: K. Nupponen). 


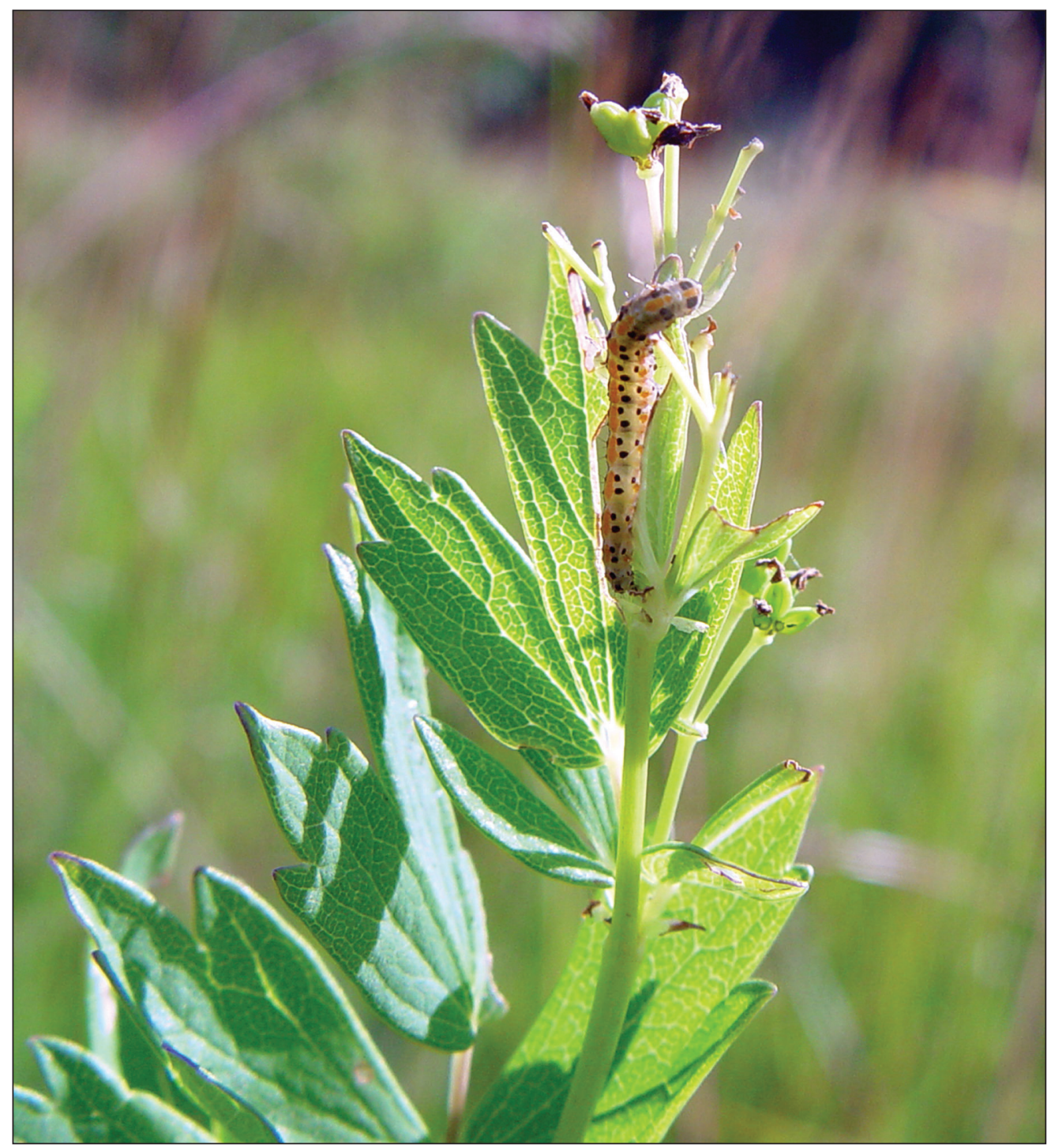

Figure 4. Larva of Ethmia pyrausta on Thalictrum flavum (Finland, Al: Finström, 19.vii.2005) (photo: $K$. Nupponen).

In the Baltic countries, the species occurs sporadically in Latvia ( ̌́ulcs and Šulcs 1978, Savenkov and Šulcs 2010) and Estonia (Nolcken 1871, Petersen 1924, Jürivete and Õunap 2008). There is also one locality for the species in northern Lithuania close to the Latvian border (Povilas Ivinskis, pers. comm.). The Finnish and Baltic records of E. pyrausta known to us are listed in Table 1.

\section{Description of the larva}

Larvae of the genus Ethmia have a chaetotaxy generally typical of Lepidoptera, with one exception: D2 setae of abdominal segment 9 are laterad of D1 unlike other Gelechioidea, but 
Table 1. Records of Ethmia pyrausta (Pallas, 1771) from Finland and the Baltic countries.

\begin{tabular}{|c|c|c|c|c|}
\hline Locality & Date & Specimens & Observer(s) & Notes \\
\hline \multicolumn{5}{|c|}{ FINLAND } \\
\hline Al: Geta & $1920 \mathrm{~s}$ & 5 & J. Montell & \\
\hline $\begin{array}{l}\text { Al: Jomala, Gottby } \\
\text { utäng }\end{array}$ & 9.v.1943 & $\begin{array}{l}1 \text { male, } 1 \text { female } \\
\text { in copula }\end{array}$ & M. Donning & \\
\hline Al: Finström & 1945 & $\begin{array}{l}\text { Ca. } 30 \text { larvae, } \\
\text { reared } 10 \text { adults }\end{array}$ & A. Nordman & \\
\hline N: Helsinki & viii.1946 & 1 larva & J. Grönvall & \\
\hline $\begin{array}{c}\text { Al: Eckerö, Öra } \\
671: 309\end{array}$ & $\begin{array}{c}1947 \& \\
1948\end{array}$ & Several larvae & $\begin{array}{l}\text { A. Nordman \& J. } \\
\text { Waselius }\end{array}$ & \\
\hline $\begin{array}{c}\text { Al: Eckerö, Skag } \\
671: 309\end{array}$ & 1948 & $\begin{array}{c}\text { Larvae, emerged } 6 \\
\text { adults }\end{array}$ & A. Nordman & \\
\hline $\mathrm{Al}:$ Geta & 1952 & $\begin{array}{l}\text { Several larvae, } \\
\text { emerged } 6 \text { adults }\end{array}$ & M. von Schantz & \\
\hline $\begin{array}{c}\text { Al: Eckerö, Skag } \\
671: 309\end{array}$ & 1952 & $\begin{array}{l}\text { Larvae, emerged } \\
\quad>30 \text { adults }\end{array}$ & H. Bruun & \\
\hline Al: Lemland & 1956 & $\begin{array}{c}\text { Larvae, emerged } 9 \\
\text { adults }\end{array}$ & O. Nylund & \\
\hline Al: Finström, Norrö & $1950 \mathrm{~s}$ & Larvae & H. Bruun & \\
\hline Al: Hammarland & $1950 \mathrm{~s}$ & $?$ & H. Bruun, unpubl. & Not confirmed \\
\hline $\begin{array}{c}\text { Al: Eckerö, Skag } \\
671: 309\end{array}$ & $1970 \mathrm{~s}$ & 1 larva & J. Kangas & $\begin{array}{l}\text { Doubtful record, identification not } \\
\text { confirmed }\end{array}$ \\
\hline Al: Lemland & 8.vii.1984 & 1 larva & E. Peltonen & $\begin{array}{c}\text { Doubtful record, identification not } \\
\text { confirmed }\end{array}$ \\
\hline Al: Finström 670:310 & 19.vii.2005 & 28 larvae & $\begin{array}{l}\text { K. Nupponen/ } \\
\text { Faunatica Oy }\end{array}$ & \\
\hline $\begin{array}{c}\text { Al: Lemland, } \\
\text { Flakaviken 667:312 }\end{array}$ & 8.vi.2006 & 1 male & $\begin{array}{l}\text { E.M. \& L. Laasonen/ } \\
\text { Faunatica Oy }\end{array}$ & \\
\hline $\mathrm{Al}$ : Finström 670:310 & 25.vii.2006 & 150 larvae & $\begin{array}{l}\text { K. Nupponen/ } \\
\text { Faunatica Oy }\end{array}$ & \\
\hline \multicolumn{5}{|c|}{ ESTONIA } \\
\hline E Saaremaa, Pihtla & $1859-1867$ & $\begin{array}{l}\text { Several males, } \\
1 \text { female }\end{array}$ & Nolcken & \begin{tabular}{|c|} 
Dates of records: \\
28.iv.-10.v.1865 several, 10.-17.v.1866, \\
29.v.-6.vi.1867 about 5 adults \\
\end{tabular} \\
\hline E Saaremaa, Pihtla & $1866-1867$ & Larvae & Nolcken & Half-grown larvae in late June, 1866 \\
\hline $\begin{array}{l}\text { Tallinn, Habersti } \\
\text { (near lake Harku) }\end{array}$ & 30.v.1900 & 2 males & Petersen (1924) & \\
\hline SE Estonia & After 1950 & $?$ & J. Luig, unpubl. & \\
\hline Tallinn, Pääsküla & 20.v.2003 & 1 male & A. Lindt & By light trap \\
\hline $\begin{array}{l}\text { SE Estonia, river } \\
\text { Piusa, Veski }\end{array}$ & v.2007 & 1 male & R. Haverinen & By light trap \\
\hline $\begin{array}{l}\text { SE Estonia, river } \\
\text { Piusa, Veski }\end{array}$ & 24.vi.2007 & $>20$ larvae & E. \& U. Jürivete & \\
\hline $\begin{array}{l}\text { SE Estonia, river } \\
\text { Piusa, Veski }\end{array}$ & 12.v.2008 & $>20$ males & E. \& U. Jürivete & \\
\hline $\begin{array}{l}\text { SE Estonia, river } \\
\text { Piusa, Veski }\end{array}$ & v.2008 & 1 male & E. Öunap & \\
\hline $\begin{array}{l}\text { SE Estonia, river } \\
\text { Piusa, Veski }\end{array}$ & 17.v.2014 & 1 male & E. \& U. Jürivete & \\
\hline \multicolumn{5}{|c|}{ LATVIA } \\
\hline Salaspils & $\mathrm{v},<1889$ & 1 & Teich & \\
\hline Salaspils & viii, $<1889$ & Larvae & Teich & \\
\hline
\end{tabular}




\begin{tabular}{|c|c|c|c|c|}
\hline Locality & Date & Specimens & Observer(s) & Notes \\
\hline Salaspils & 16.v.1976 & 13 & A. \& I. Šulcs & \\
\hline Salaspils & 21.v.1977 & 1 & A. \& I. Šulcs & \\
\hline Salaspils & 22.v.1978 & 6 & A. \& I. Šulcs & \\
\hline $\begin{array}{l}\text { Krievupe (Riga } \\
\text { district) }\end{array}$ & 5.vi.1987 & 1 male & A. Titov & \\
\hline $\begin{array}{l}\text { W-Latvia, Kemeri } \\
\text { (Apšupe) }\end{array}$ & 1.vi.1993 & 1 male & N. Savenkov & \\
\hline $\begin{array}{l}\text { W Latvia, Kemeri } \\
\text { (Kūdra) }\end{array}$ & 23.v.1995 & 1 male & A. Titov & \\
\hline $\begin{array}{l}\text { W Latvia, Kemeri } \\
\text { (Kūdra) }\end{array}$ & 10.v. 1998 & 1 male & A. Titov & \\
\hline SE Latvia, Šķaune & v. 2005 & 1 male & I. Šulcs & By light \\
\hline SE Latvia, Šḳaune & 6.vii.2006 & Several larvae & N. Savenkov & \\
\hline \multicolumn{5}{|c|}{ LITHUANIA } \\
\hline $\begin{array}{c}\text { N Lithuania, } \\
\text { Dukstyna reserve } \\
\text { (near Ukmerge town) }\end{array}$ & 1970s & Larvae & P. Ivinskis & \\
\hline
\end{tabular}

similar to Cryptolechiinae (Kaila 2004, Heikkilä et al. 2014). Setae A1-3 and L1 on head form a nearly straight line, and secondary setae are present on abdominal SV groups, including both the prolegs and the $9^{\text {th }}$ abdominal segment. E. pyrausta differs from other ethmiine species by having secondaries only on 9 th abdominal segment.

Head morphology: Head semiprognathous, rather rounded, surface smooth but not shining, frontoclypeus slightly longer than epicranial suture, adfrontal suture joined to epicranial suture before vertical notch. Six stemmata present on each side, nearly equal in size but stemma 2 slightly smaller, stemmata 5 and 6 in line with caudal margin of antennal socket. Spinneret tubular, tapering distad and proximad, about three times as long as wide. Labial palpi slender, segment Lps1 two times longer than wide, seta Lp1 about twice as long as segment Lps2, seta Lp2 as long as Lps1 (Fig. 5). Stipular setae shorter than Lp2 of labial palpi, position on chitinised part of prementum. Hypopharynx largely bare, median and lateral parts of posterior region covered with tiny spines (Fig. 6). Laciniogalea of maxillae with stout sensilla, Ss2 thicker than Ss1 on galeal lobe and St1 thinner than St2-3. Maxillary palpi with stout third segment, longer than second one (Fig. 7). Cutting margin of mandible with very tiny ventral tooth and with straight and smooth edge of second dorsal tooth. Other teeth unspecialized. Three inner ridges present on inner surface of mandible. Labrum with low and rather large notch, seta LR1 situated on level with LR2, setae LR5 and LR6 separately on line with seta LR4 (Fig. 8).

Chaetotaxy: Position of P1 setae on level with AF2 on head, distance P1-P1 shorter than P2-P2, setae A1, A2 and A3 situated straight on line. Setae D1 and D2 of prothoracic shield close to each other, seta SD2 also on shield but SD1 not. Three L setae and two SV setae present on prothorax; L1 distinctly ventrad of L2 and L3. Thoracic segments Th2-3 have D1 and D2 setae close to each other and SD1 close to SD2, all on same pinaculum, seta SV1 on large pinaculum and microseta MD1 also on pinaculum. Three L setae and two MSD microsetae without pinacula, one additional sclerotized plate present behind D setae (Fig. 9). Abdomen has large pinacula separately around D1 and D2 setae on segments Ab1-7, position of seta D1 cephalad from D2 on segment Ab9, setae SD1 and SD2 on same pinaculum on segments 


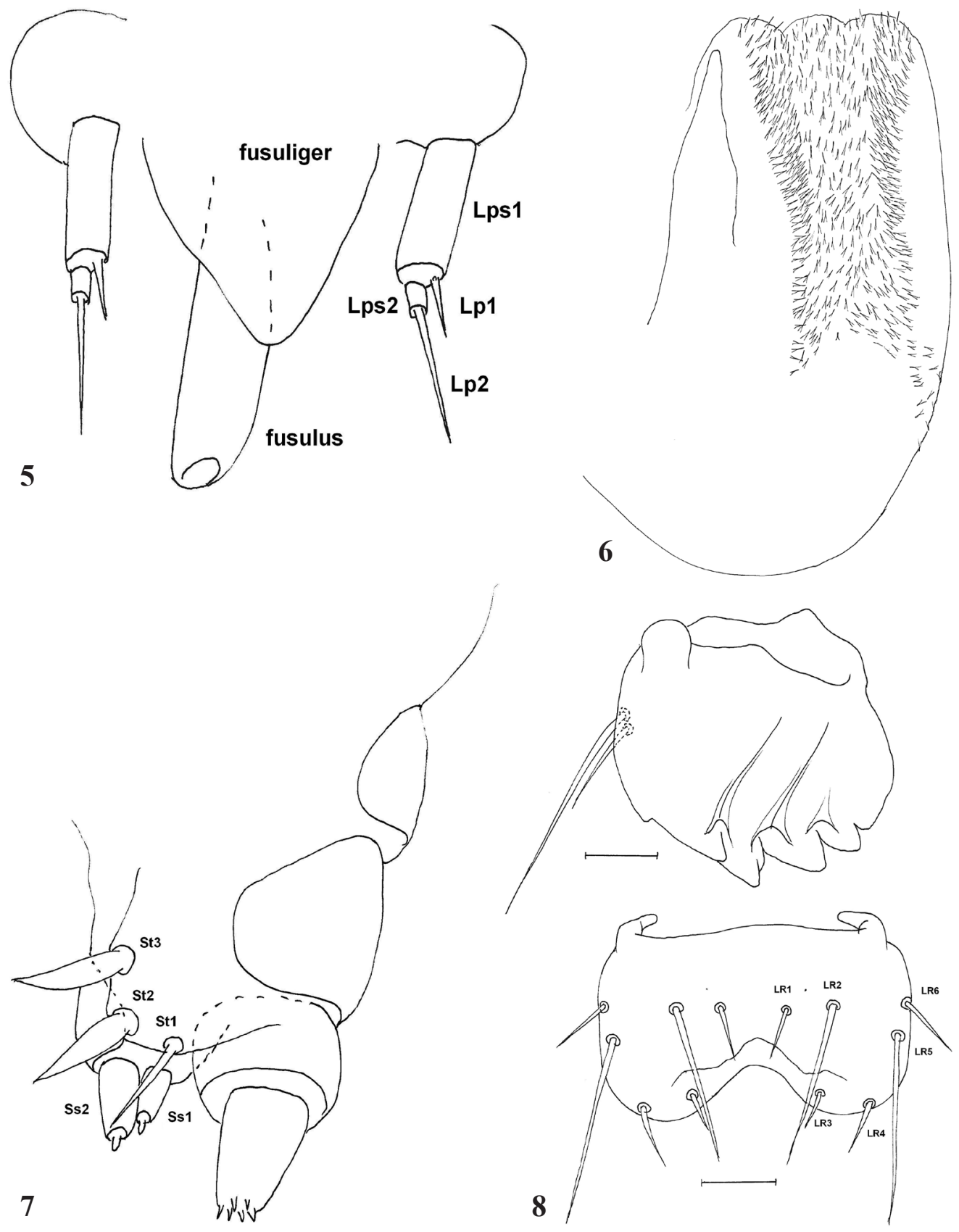

Figure 5-8. Ethmia pyrausta: 5. Morphology of mouthparts, spinneret and labial palpi in dorsal view; 6. Hypopharynx from dorsal view; 7. Maxillae with maxillary palpi and sensilla of galeal and lacinial area; 8. Labrum and left mandible (scale bar $=0.1 \mathrm{~mm}$ ). 
Ab1-8 and larger pinacula around setae L3 and V1 on segments Ab1-7. Setae L1 and L2 situated close to each other on segments Ab1-9, seta L3 present also on segment Ab9. Small pinaculum around seta L2 on segments Ab1-5. Three SV setae present on segments Ab1-6, two SV setae on segments Ab7-8 and one long SV and numerous secondary setae on segment Ab9 (Fig. 10). Anal shield with D1 setae on level with SD2, setal distance D2-D2 longer than D2-SD1 and small spines present between setae D2-D2 (Fig. 9). Seta D2 long on abdominal segments Ab1-Ab9 but seta SD1 longer on anal shield. Crochets of abdominal prolegs biordinal in mesal penellipse.

Larval habitus: Head smooth with pale green postclypeus, adfrons, dorsal part of frons and narrow stripe from adfrons behind stemmata; head otherwise black. Sides of prothoracic shield and pinacula of body black. Broad orange flecks in place of middorsal and spiracular lines, dorsal zone between middorsal line and D2 setae dark greenish especially on thorax, but larva otherwise dull white.

\section{Notes on the biology}

The habitats of E. pyrausta are open and sunny moist meadows, often located at the shore or riverside (Fig. 3). Ovipositing females apparently prefer microhabitat with rather sparse, lower vegetation and warmer microclimate than in the adjacent grassy areas. Usually such a habitat exists as a narrow belt between forest and dense stands of Salix or Phragmites. The species has never been found in forests, even in localities where the host plant is abundant in semi-shadowed open patches within the forest. A common feature for localities of E. pyrausta is that they are open to the southeast or east, and sunshine reaches the spots in the early morning.

The larva is oligophagous on Thalictrum species (Ranunculaceae). In Finland, the only recorded host plant is Thalictrum flavum L. (Fig. 4), probably due to the fact that other species of Thalictrum do not occur or are very rare in the region where E. pyrausta occurs. In Estonia, larvae have also been found on Thalictrum aquilegiifolium L. (Nolcken 1871, Petersen 1924) and T. lucidum L. (E. \& U. Jürivete, pers. comm.). In an average season, larvae are of detectable size from late June and they pupate in the first half of August. They feed on flower-buds, flowers and seeds. Full-grown larvae feed also on leaves, but only when all seeds are eaten up. Larvae live singly and freely on the host plant, although sometimes two to three larvae have been observed on one plant. Contrary to what is stated in the literature (e.g. Emmet 1979) we did not detect any webs made by larvae on the plants. The presence of larvae can be presumed from the evidence of partly eaten seeds. However, larvae of some other Lepidoptera feed on seeds of Thalictrum too, and sometimes they occur sympatrically with E. pyrausta, e.g., the geometrid Gagitodes sagittatus (Fabricius, 1787). Therefore, the occurrence of E. pyrausta should always be confirmed by direct observation of a larva, not just by feeding damage.

Larval behaviour was studied three times: twice on the Åland Islands (19.vii.2005 and 25.vii.2006) and once in the south-eastern Estonia (24.vi.2007). The larva is predominantly nocturnal. On Åland, three larvae were observed on 19.vii.2005 at 6 p.m. and 25 larvae from 11:30 p.m. to 00:15 a.m. (local summer time, i.e. +3 h GMT). On 25.vii.2006 in the same locality, there were no signs of larvae earlier in the day (3-4 p.m.), while about 150 almost full-grown larvae were observed at night from 11:30 p.m. to 1 a.m. In SE Estonia, altogether more than 20 larvae of various ages were observed on 24.vi.2007 at dusk. Larvae become active at dusk, and climb 


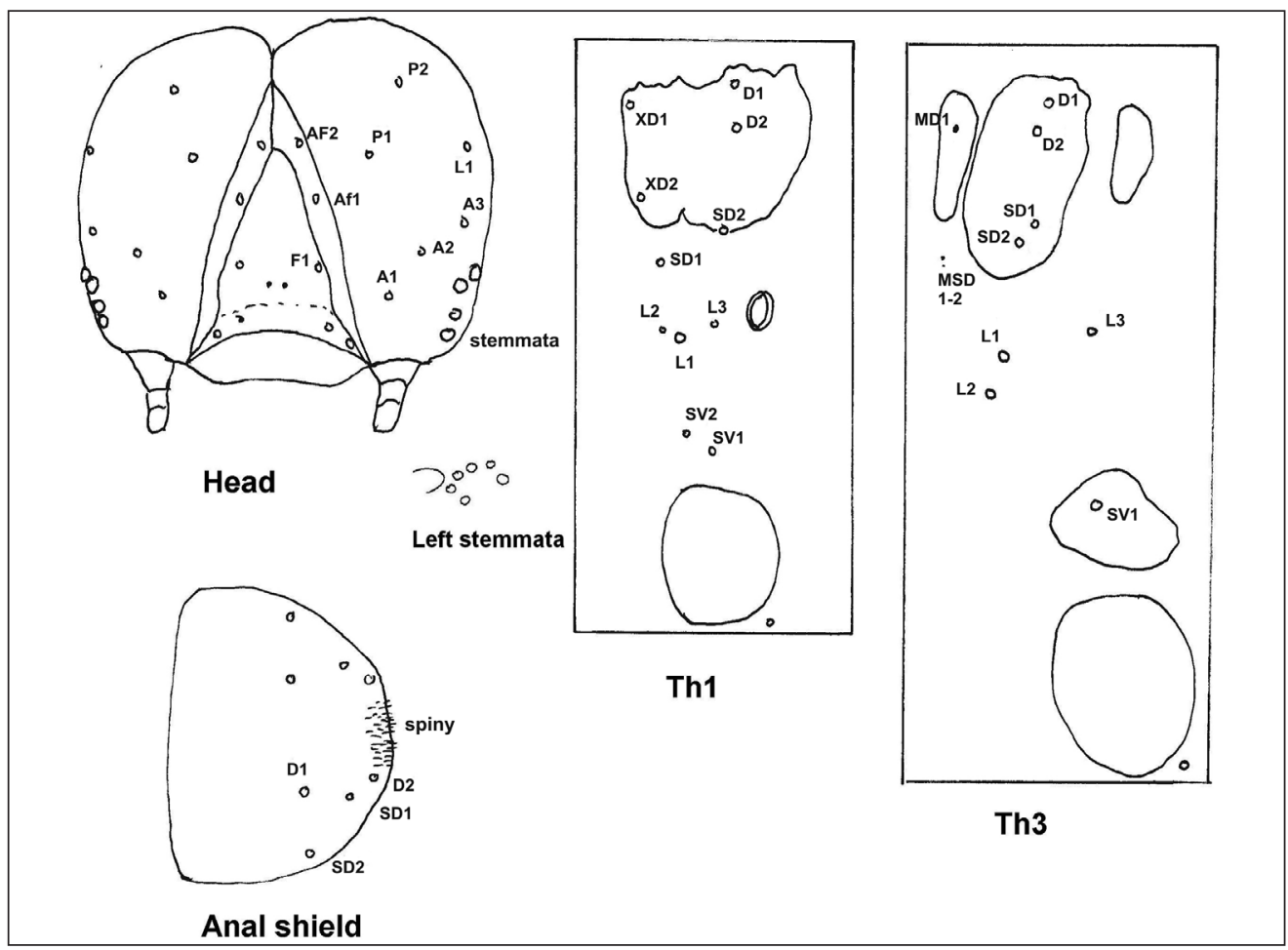

Figure 9. Ethmia pyrausta: Chaetotaxy of head, thorax and anal shield, and left stemmatal ring.

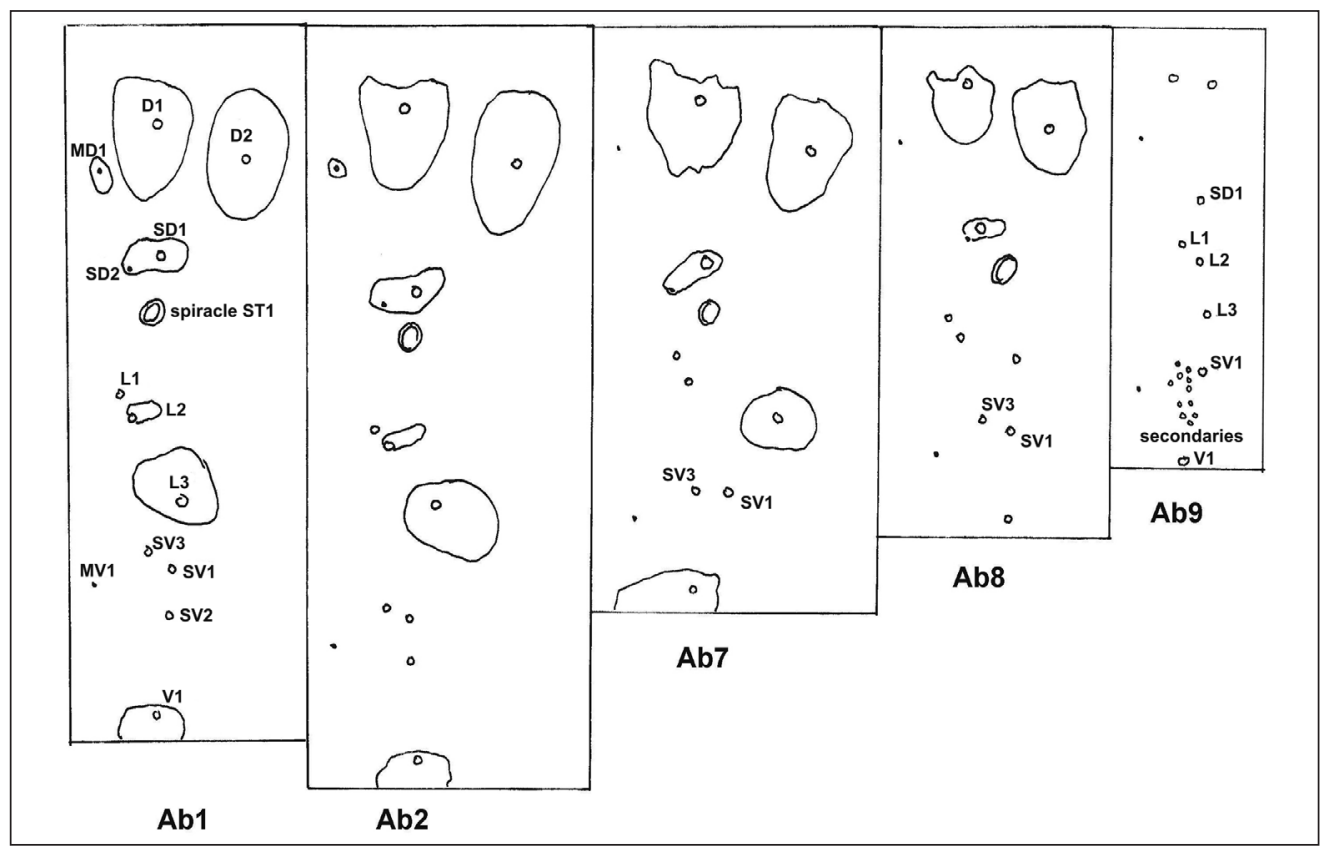

Figure 10. Ethmia pyrausta: Chaetotaxy of abdomen. 
onto the host plant to eat seeds. They eat during a rather brief period (maximally half an hour), and then return to hide in the litter. The larvae move rapidly and drop onto the ground very easily when disturbed. Later at night they are less active, possibly due to decreasing temperature and especially fog that often forms in such habitats at night. During the second half of the night and daylight, larvae are mainly hiding in the soil, and only occasionally visit their host plants to feed. Nolcken (1871) detected larvae on their host during daylight, but he did not present further notes on the time of the records. Pupation takes place in a dirty white or pale yellow cocoon in detritus on the ground. We did not rear any parasitoids from the larvae. It is also possible that the behaviour of parasitized larvae changes and, thus, they cannot be observed with the same methods.

The main flight period is in May with a peak about one to two weeks after budburst of birch. In years with a late season and close to the seashore, the flight period starts later and extends even to mid-June. Nolcken (1871) recorded adults in the period 28 April to 6 June (in 1865-1867), but the annual flight period did not last more than two weeks. The adult of $E$. pyrausta is predominantly diurnal. Occasionally, males fly at night too and come to light, usually on extremely warm nights. In south-eastern Estonia, the behaviour of adults was studied on 12.v.2008. The previous night was cold and the temperature decreased to $+1^{\circ} \mathrm{C}$ in the second half of the night. In the morning, the sky was clear and sunshine heated the wet vegetation from early morning. The first E. pyrausta male was observed at 7:30 a.m., while the temperature was still low. Most males became active just after 8 a.m., and over 20 individuals were observed between 8 a.m. and 9 a.m. After that, flight virtually stopped. During the active flight period, males were flying rather slowly and close to the ground (height of flight about $1 \mathrm{~m}$ ), probably searching for females. Šulcs and Šulcs (1978) recorded similar 'swarming' of E. pyrausta in early morning. Males appear to re-activate at the middle part of the day between 10 a.m. and 2 p.m., when the moths fly rapidly, straighter and higher (height of 2.5-3 m) than in the morning (Nolcken 1871; U. Jürivete unpublished; E. Ounap pers. comm.). It is difficult to observe rapidly flying dark moths, and because of that, the species is seldom recorded by chance. As far as we know, there are no records of an evening flight of E. pyrausta. Females do not seem to fly much, but prefer to sit among the vegetation and presumably attract males.

\section{Conservation}

Ethmia pyrausta shows a highly sporadic distribution throughout its known range. It has apparently declined at least in the western parts of the range. For example, the occupancy of $E$. pyrausta was systematically studied in 34 patches of T. flavum - including traceable previous findings - throughout the Åland Islands in 2005 and 2006, but it was present in only one open and sunny patch (Fig. 3) (Nupponen et al. 2007). On the other hand, the population in that patch was relatively large. Based especially on the negative trends in various habitat characteristics, e.g. decreasing amount and quality and high degree of fragmentation, the species has been rated as threatened both in Finland (Kaitila et al. 2010; CR: criteria B1ab(iii)c(iv)+2ab(iii)c(iv)) and Sweden (Bengtsson et al. 2010; EN: criteria B2ab(i,ii,iii,iv,v)).

Ethmia pyrausta requires host plants that are growing in full sunshine. Therefore, the main reason for the decline, at least in Finland and Sweden, is overgrowing of moist meadows after cessation of grazing. All management activities should be performed late in the season, i.e. in August at the earliest. This should ensure that E. pyrausta larvae have time to pupate before management 
starts. Further, Thalictrum is highly vulnerable to grazing (Anonymous 2014; own observations) and only late-season grazing or mowing can be recommended. Unfortunately, such late-season management has almost ended in Sweden and Finland, even though plenty of herbivorous insect species are highly dependent on it (Dahlström et al. 2008). In management, the first thing to take care of is to create and maintain open sunny patches of moist meadow with plenty of host plants. Habitats occupied by E. pyrausta are regularly dominated by Filipendula ulmaria (Rosaceae), and usually the main aim is to reduce its abundance by mowing. If meadows are mown, only areas without Thalictrum should be cut. However, in meadows that are grazed earlier than recommended, F. ulmaria protects plants growing among it against grazing, so reasonable amounts of F. ulmaria in microhabitats with Thalictrum are beneficial in those cases (Anonymous 2014).

\section{Acknowledgements}

We thank the following colleagues for various help in preparing the present article: Bengt $\AA$. Bengtsson (Färjestaden, Sweden), Pavel Gorbunov (Ekaterinburg, Russia), Povilas Ivinskis (Vilnius, Lithuania), Ene Jürivete (Tallinn, Estonia), Aleksander Lagunov (Miass, Russia), Elena Nupponen (Espoo, Finland), Timo Nupponen (Espoo, Finland), Vladimir Olschwang (Ekaterinburg, Russia), Nils Ryrholm (Gävle, Sweden), Nikolay Savenkov (Riga, Latvia), Kimmo Silvonen (Espoo, Finland), Ivars Šulcs (Riga, Latvia). Our thanks are also due to Lauri Kaila (Helsinki, Finland), Wolfram Mey (Berlin, Germany) and Erik van Nieukerken (Leiden, Netherlands) for constructive comments on the manuscript. Ålands landskapsregering (provincial government) supported our research on Åland Islands by permits and funding.

\section{References}

Ahola M, Silvonen K (2005) Pohjoisen Euroopan yökkösten toukat. Larvae of Northern European Noctuidae. Osa 1, Vol. 1. Vammalan Kirjapaino Oy, Sastamala, 657 pp.

Anonymous (2014) Ethmia pyrausta. http://butterfly-conservation.org/48-6127/rare-moth-found-in-scottish-highlands.html [accessed 8.i.2015]

Bengtsson BÅ, Björklund JO, Cederberg B, Eliasson C, Franzén M, Hydén N, Lindeborg M, Palmqvist G, Ryrholm N, Söderström B (2010) Fjärilar-Butterflies and moths-Lepidoptera. In: Gärdenfors U (Ed.) Rödlistade arter i Sverige 2010 - The 2010 Red List of Swedish Species. ArtDatabanken, SLU, Uppsala, 361-392.

Dahlström A, Lennartsson T, Wissman J, Frycklund I (2008) Biodiversity and traditional land use in south-central Sweden - The significance of management timing. Environment and History 14: 385 403. doi: 10.3197/096734008X333572

Dubatolov VV, Ustjuzhanin PYa, Zintshenko VK (1997) A review of the Ethmiidae of the Asian part of Russia and neighbouring territories. Atalanta 28(1/2): 161-171.

Dubatolov VV (2014) Ethmidae of the former USSR and neighbouring countries. http://szmn.eco.nsc.ru/ vvdubat/pdf/ethmussr.htm [accessed 29.12.2014]

Gustafsson B (2012) Svenska fjärilar: Ethmia pyrausta. http://www2.nrm.se/en/svenska_fjarilar/e/ethmia_pyrausta.html [accessed 8.1.2015]

Heikkilä M, Mutanen M, Kekkonen M, Kaila L (2014) Morphology reinforces proposed molecular phylogenetic affinities: a revised classification for Gelechioidea (Lepidoptera). Cladistics 30: 563-589. doi: $10.1111 /$ cla.12064 
Hinton HE (1946) On the homology and nomenclature of the setae of the lepidopterous larvae, with some notes on the phylogeny of the Lepidoptera. The Transactions of the Royal Entomological Society of London 97: 1-37.

Hyönteistietokanta (2014) Hyönteistietokanta. http://hyonteiset.luomus.fi/insects/main/EntDatabase. html\#search-LEP [accessed 29.12.2014]

Jürivete U, Õunap E (2008) Eesti Liblikad. Kataloog - Estonian Lepidoptera. Tallinn, 175 pp.

Kaila L (2004) Phylogeny of the superfamily Gelechioidea (Lepidoptera: Ditrysia): an exemplar approach. Cladistics 20: 303-340. doi: 10.1111/j.1096-0031.2004.00027.x

Kaitila JP, Nupponen K, Kullberg J, Laasonen E (2010) Perhoset-Butterflies and Moths-Lepidoptera. In: Rassi P, Hyvärinen E, Juslén A, Mannerkoski I (Eds) Suomen lajien uhanalaisuus - Punainen kirja 2010. Ympäristöministeriö, Suomen Ympäristökeskus, 430-470.

Kimber I (2014) UK Moths, Ethmia pyrausta. http://ukmoths.org.uk/show.php?bf=722 [accessed $8.1 .2015]$

Nolcken JHW (1871) Lepidopterologische Fauna von Estland, Livland und Kurland, Vol. 2 - Microlepidoptera. Arbeiten des Naturforscher - Vereins zu Riga, Riga, 517-521.

Nupponen K (in press) Interesting records of Ethmiinae (Lepidoptera, Gelechioidea, Elachistidae) from the former USSR, with description of Ethmia ustyurtensis Nupponen, sp. n. from Kazakhstan. SHILAP Revista de Lepidopterologia.

Nupponen K, Nieminen M, Sundell P (2007) Ahvenanmaalla rauhoitettujen perhosten nykytila. Parts I, II. Unpublished report to Ålands landskapsregering. Faunatica Oy, Espoo, 432 pp.

Petersen W (1924) Lepidopteren - Fauna von Estland (Eesti). Tallinn, 503-504.

Sattler K (1967) Ethmiidae. In: Amsel HG, Gregor F, Reisser H (Eds) Microlepidoptera Palaearctica 2 (1+2). Georg Fromme, Wien, 185 pp.

Savenkov N, Šulcs I (2010) Latvijas Tauriņi. Katalogs - Latvian Lepidoptera. Tallinn, 176 pp.

Sinev SY (2008) Ethmiidae. In: Sinev SY (Ed.) Catalogue of the Lepidoptera of Russia. St. Petersburg - Moscow, $52 \mathrm{pp}$.

Šulcs A, Šulcs I (1978) Neue und wenig bekannte Arten der Lepidopteren - Fauna Lettlands, 7 - Mitteilung. Notulae Entomologicae 58: 141-150. 